DOI: $10.31393 /$ reports-vnmedical-2018-22(4)-12

UDC: $16.379-008.64$

\title{
EXPERIENCE OF LOCAL USING OF PLATELET-RICH PLASMA IN 25 PATIENTS WITH DIABETIC FOOT
}

\section{Petrushenko V.V.' , Grebeniuk D.I. ${ }^{1}$, Apasova N. V. ${ }^{2}$}

${ }^{1}$ National Pirogov Memorial Medical University, Vinnytsya (Pirogov str., 56, Vinnytsya, Ukraine, 21018),

2Vinnitsa Regional Clinical Highly Specialized Endocrinology Center (Michurina str., 32, Vinnytsya, Ukraine, 21000)

Received 21 September 2018; Accepted 5 November 2018

Responsible for correspondence: e-mail: Doctor.Svo@gmail.com

Annotation. The aim of the study was to evaluate the effectiveness of local using of autologous platelet-rich plasma in the treatment of patients with diabetic foot in stage 2. The study included 25 patients with a diagnosis of diabetic foot in stage 2 . At the time of inclusion in the study, all patients had a defect of 3-7 $\mathrm{cm}^{2}$ of the skin and subcutaneous adipose tissue in the plantar part of the foot. In addition to the standard treatment, it was decided to perform the local administration of autologous platelet-rich plasma in all patients. The entire platelet-rich plasma volume obtained was injected in the edge of skin around the wound using 30-gauge needles. Repeated injections were performed every 5-7 days until complete healing of the soft tissue defect. To evaluate the effectiveness of the treatment, the area of the ulcerative defect was measured before the manipulation, as well as at an interval of 14 days until the ulcer was completely healed. The following results are obtained: prior to the manipulation, the area of ulcerative defects in the examined population was $511.9 \pm 120.3 \mathrm{~mm}^{2}$. On the 14 th day, this indicator was already $353.6 \pm 112.5 \mathrm{~mm}^{2}$ and was significantly different from the area of the ulcerative defects before manipulation $(p<0.01)$. On the 28th day, complete healing of diabetic ulcers was observed in 11 (44\%) patients, and the area of the skin defect in the study population was $22.4 \pm 24.3 \mathrm{~mm}^{2}$ and was significantly different from those in all previous study dates $(p<0.01)$. On day 42 , we noted the complete healing of ulcers in absolutely all patients. Thus, local injection of an autologous platelet-rich plasma improves the local regenerative process and leads to complete healing of stage 2 diabetic ulcers with an area of $3-7 \mathrm{~cm}^{2}$ for 6 weeks.

Keywords: diabetic foot, platelet-rich plasma, reparation.

\section{Introduction}

Diabetes mellitus is a metabolic disease with main symptom of hyperglycemia caused by impaired insulin secretion and/or insulin interaction with tissue cells. Chronic hyperglycemia leads to dysfunction of various organs, especially the eyes, kidneys, nerves, heart and blood vessels. The prevalence of ulcerative lesions of the lower extremities caused by diabetes mellitus is estimated to be in the range of $4-10 \%$. In a cohort of patients with diabetic foot, approximately $12-20 \%$ of patients need the performing of amputations [1, 4]. In addition to the problem of diabetic angiopathy and neuropathy, attention should be paid to the fact that the condition of patients with diabetic foot may be complicated by the addition of infection, atherosclerosis of peripheral arteries [3].

Long-lasting ulcers are a serious complication in patients with diabetes. Despite active research, diabetes is not amenable to radical treatment, and ulcerative lesions of the foot, which is the most frequent localization of the process, are difficult to treat [2].

Standard treatment of diabetic ulcers includes necrotomy, treatment of the infectious process, mechanical unloading, control of blood glucose levels [1, 4], as well as various methods of local and systemic stimulation of repair [6].

Cell therapy with platelet-rich plasma (PRP) provides a completely new approach to the treatment of diabetic ulcers, which can help avoid limb loss. PRP is a plasma fraction of autologous blood with a high concentration of platelets. Platelets contain a complete set of coagulation factors, growth and differentiation (insulin-like growth factor, platelet growth factor, transforming growth factor, vascular endothelial growth factor, epidermal growth factor, fibroblast growth factor) in alpha granules, which contribute to the regeneration process. PRP reduces the inflammatory response, activates the function of macrophages and phagocytes in the wound, which leads to neoangiogenesis and epithelialization of the tissue defect [5].

The aim of the study was to evaluate the effectiveness of local using of autologous platelet-rich plasma in the treatment of patients with diabetic foot in stage 2 .

\section{Materials and methods}

All the procedures were performed according to the ethical standards of the institutional and national research committee, as well as the 1964 Helsinki Declaration and its later changes or comparable ethical standards.

The study was performed at the Department of Endoscopic and Cardiovascular Surgery of National Pirogov Memorial Medical University, Vinnytsya and included 25 patients with a diagnosis of diabetic foot in stage 2 . At the time of inclusion in the study, all patients had a defect of the skin and subcutaneous adipose tissue in the plantar part of the foot. The areas of defects were 3-7 $\mathrm{cm}^{2}$. All ulcers were not corrected by traditional methods for 2-6 months. All patients lacked any comorbidities that could affect the healing of ulcers. In addition to the standard treatment, it was decided to perform the local administration of autologous PRP in all patients.

PRP was prepared according to the following procedure. 
Total volume of $8 \mathrm{ml}$ of blood was sampled from the cubital vein in each patient. PRP was prepared in sterile heparinized plastic test tubes, the heparin content in which was 14-20 U/ $\mathrm{ml}$ of blood. The blood was centrifuged in a 80-2 centrifuge at a speed of $1500 \mathrm{rpm}$ for 8 minutes, which resulted in about $4.5-5 \mathrm{ml}$ of platelet-rich plasma. As a result of centrifugation, the blood was divided into two layers: the upper layer - platelet-rich plasma, the lower layer erythrocytes and leukocytes with an insignificant admixture of platelets, which were located in the upper part of the layer. The entire upper layer and about $2 \mathrm{~mm}$ of the upper part of the lower layer were taken into a separate sterile syringe.

The entire PRP volume obtained was injected in the edge of skin around the wound using 30-gauge needles. Repeated injections were performed every 5-7 days until complete healing of the soft tissue defect.

To evaluate the effectiveness of the treatment, the area of the ulcerative defect was measured before the manipulation, as well as at an interval of 14 days until the ulcer was completely healed.

The obtained data were processed using the statistical software package SPSS 20.0 for Windows.

\section{Results. Discussion}

Prior to the manipulation, the area of ulcerative defects in the examined population was $511.9 \pm 120.3 \mathrm{~mm}^{2}$. On the 14 th day, this indicator was already $353.6 \pm 112.5 \mathrm{~mm}^{2}$ and was significantly different from the area of the ulcerative defects before manipulation $(p<0.01)$. On the 28th day, complete healing of diabetic ulcers was observed in 11 (44\%) patients, and the area of the skin defect in the study population was $22.4 \pm 24.3 \mathrm{~mm}^{2}$ and was significantly different from those in all previous study dates $(p<0.01)$. On day 42 , we noted the complete healing of ulcers in absolutely all patients.

The dynamics of the healing of diabetic ulcers is shown in Figure 1.

The gold standard for treating diabetic ulcers is the treatment of an ulcer, infection control, revascularization, and stimulation of repair. Other advanced methods have also been proposed as adjuvant therapies, such as hyperbaric oxygen therapy, VAC therapy. However, at the moment, insufficient data have been collected regarding their clinical and costeffectiveness in the treatment of the diabetic foot [2].

\section{References}

1. Abredari, H., Bolourchifard, F., Rassouli, M., Nasiri, N., Taher, M. \& Abedi, A. (2015). Health locus of control and self-care behaviors in diabetic foot patients. Med. J. Islam. Repub. Iran, 29, 283. Retrieved from https://www.ncbi.nlm.nih.gov/ pmc/articles/PMC4764266/.

2. Andrews, K. L., Houdek, M. T. \& Kiemele, L. J. (2015). Wound management of chronic diabetic foot ulcers: from the basics to regenerative medicine. Prosthet Orthot. Int., 39 (1), 29-39. DOI: $10.1177 / 0309364614534296$.

3. Hicks, C. W., Selvarajah, S., Mathioudakis, N., Sherman, R. E. Hines, K. F., Black, J. H. 3rd. \& Abularrage, C. J. (2016). Burden of Infected Diabetic Foot Ulcers on Hospital Admissions and Costs. Ann. Vasc. Surg., 33, 149-158. DOI: 10.1016/

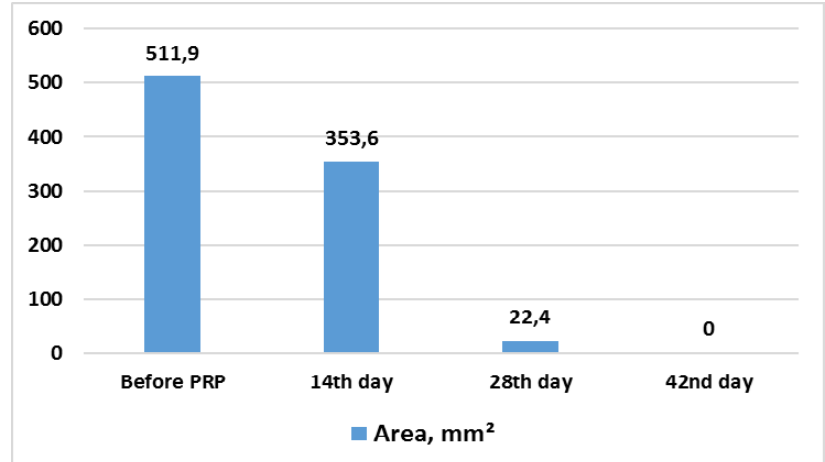

Fig. 1. Dynamics of healing of diabetic ulcers in the studied population.

Autologous platelet-rich plasma is a promising alternative to traditional methods, promoting safe and natural healing. Platelets contain in alpha granules a complete set of coagulation factors, growth and differentiation, which contribute to the regeneration process. PRP reduces the inflammatory response, activates the work of macrophages and phagocytes in the wound, which leads to neoangiogenesis and epithelialization of the tissue defect [6].

Our experience of using autologous platelet-rich plasma in the treatment of patients with diabetic foot in stage 2 demonstrated the effectiveness of this technique. A progressive significant $(p<0.01)$ decrease in the area of the ulcerative defect starting from 14 days was noted. We have been able to achieve complete healing of diabetic ulcers in $44 \%$ of patients on day 28 and in $100 \%$ of patients on day 42. It should be noted that prior to our use of platelet-rich plasma, all patients were unsuccessfully treated with standard therapy for 2-6 months.

\section{Conclusions and prospects for further research}

1. Local injection of an autologous platelet-rich plasma improves the local regenerative process and leads to complete healing of stage 2 diabetic ulcers with an area of 3-7 $\mathrm{cm}^{2}$ for 6 weeks.

In the future, it is planned to continue the collection of clinical material, its statistical processing and critical analysis.

j.avsg.2015.11.025.

4. Kadam, D. (2016). Microsurgical Reconstruction of Plantar Ulcers of the Insensate Foot. J. Reconstr. Microsurg., 32 (5), 402-410. doi:10.1055/s-0036-1579536.

5. Picard, F., Hersant, B., Bosc, R. \& Meningaud, J. P. (2015). The growing evidence for the use of platelet-rich plasma on diabetic chronic wounds: A review and a proposal for a new standard care. Wound Repair Regen, 23 (5), 638-643. DOI: 10.1111/ wrr.12317.

6. Zhang, Z. \& Lv, L. (2016). Effect of local insulin injection on wound vascularization in patients with diabetic foot ulcer. Exp. Ther. Med., 11 (2), 397-402. 


\section{ДОСВІД ЛОКАЛЬНОГО ЗАСТОСУВАННЯ ПЛАЗМИ, ЗБАГАЧЕНОЇ ТРОМБОЦИТАМИ, У 25 ПАЦІЄНТІВ ІЗ ДІАГНОЗОМ ДІАБЕТИЧНОї СТОПИ \\ Петрушенко В.В., Гребенюк Д.И., Апасова Н.В.}

Анотація. Метою дослідження було оцінити ефективність локального застосування аутологічної, плазми збагаченої тромбоцитами в лікуванні пацієнтів з діабетичною стопою в стадії 2. У дослідження були включені 25 пацієнтів із діагнозом діабетичної стопи в стадії 2. На момент включення в дослідження всі пацієнти мали дефект шкіри та підшкірної жирової

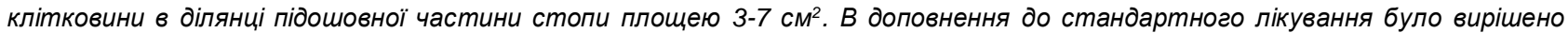
провести місцеве введення аутологічної плазми збагаченої тромбоцитами всім пацієнтам. Весь отриманий об'єм плазми, збагаченої тромбоцитами, вводили в край шкіри навколо рани за допомогою голок 30-го калібру. Повторні ін'єкції проводили кожні 5-7 днів до повного загоєння дефекту м'яких тканин. Для оцінки ефрективності лікування площу виразкового дефекту вимірювали до маніпуляції, а також з інтервалом в 14 днів до повного загоєння виразки. Отримані наступні результати: до

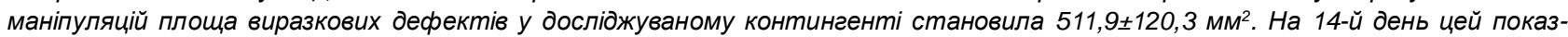

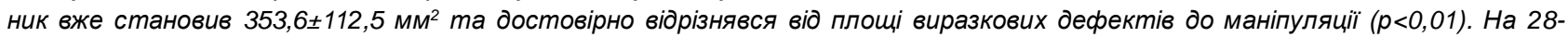
й день повне загоєння діабетичних виразок спостерігалося у 11 (44\%) пацієнтів, а площа дефректу шкіри в досліджуваному

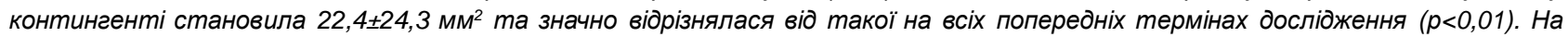
42 день було відмічено повне загоєння виразкових дефектів абсолютно у всіх пацієнтів. Таким чином, локальне введення аутологічної плазми, збагаченої тромбоцитами, покращує місцевий регенеративний процес і призводить до повного загоєння діабетичних виразок у стадії 2 площею 3-7 см² протягом 6 тижнів.

Ключові слова: діабетична стопа, плазма, збагачена тромбоцитами, репарація.

\section{ОПЫТ ЛОКАЛЬНОГО ПРИМЕНЕНИЯ ПЛАЗМЫ, ОБОГАЩЁННОЙ ТРОМБОЦИТАМИ, У 25 ПАЦИЕНТОВ С ДИАГНОЗОМ ДИАБЕТИЧЕСКОЙ СТОПЫ \\ Петрушенко В.В., Гребенюк Д.И., Апасова Н.В.}

Аннотация. Целью исследования было оценить эффрективность локального применения аутологичной плазмы, обогащённой тромбоцитами, в лечении пациентов с диабетической стопой в стадии 2. В исследование были включены 25 пациентов с диагнозом диабетической стопы в стадии 2. На момент включения в исследование все пациенты имели дефект кожи и подкожной жировой клетчатки в области подошвенной части стопы площадью 3-7 см². В дополнение к стандартному лечению было решено провести местное введение аутологичной плазмы, обогащённой тромбоцитами, всем пациентам. Весь полученный объём плазмы, обогащённой тромбоцитами, вводили в край кожи вокруг раны с помощью игл 30-го калибра. Повторные инъекции проводили каждые 5-7 дней до полного заживления дефекта мягких тканей. Для оценки эфффективности лечения площадь язвенного дефекта измеряли до манипуляции, а также с интервалом в 14 дней до полного заживления язвы. Получены следующие результаты: до манипуляций площадь язвенных дефектов в исследуемом контин-

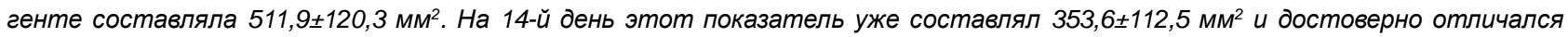
от площади язвенных дефектов до манипуляции $(p<0,01)$. На 28-й день полное заживление диабетических язв наблюдалось у 11 (44\%) пациентов, а площадь дефекта кожи в исследуемом контингенте составляла 22,4 24,3 мм² и значительно отличалась от таковой на всех предыдущих терминах исследования (p<0,01). На 42 день было отмечено полное заживление язвенных дефектов абсолютно у всех пациентов. Таким образом, локальное введение аутологичной плазмы, обогащённой тромбоцитами, улучшает местный регенеративный процесс и приводит к полному заживлению диабетических язв в

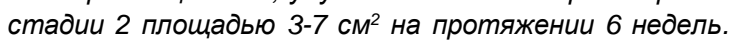

Ключевые слова: диабетическая стопа, плазма, обогащённая тромбоцитами, репарация. 